Original Research

\title{
Response of the Wumeng Sheep to Phosphorus Deprived Environment in the Southwest China
}

\author{
Kui Zhao', Xiaoying Min', Xiaoyun Shen ${ }^{1,2,3 *}$ \\ ${ }^{1}$ School of Materials and Architectural Engineering, Guizhou Normal University, Guiyang 550025, China \\ ${ }^{2}$ School of Life Science and Engineering, Southwest University of Science and Technology, \\ Mianyang 621010, Sichuan, China \\ ${ }^{3}$ World Bank Poverty Alleviation Project Office in Guizhou, Southwest China, Guiyang 550004, Guizhou, China
}

Received: 20 March 2020

Accepted: 10 October 2020

\begin{abstract}
The objective of this study was to determine the response of the Wumeng sheep on phosphorus (P) deprived range in the Southwest China. Samples of herbage, soil and animal tissue were collected in the studied area. Physiological and biochemical values in blood were examined. The mineral contents were determined in soils, forages and animal tissues (blood, bone, wool). The results showed that $\mathrm{P}$ contents in soil and forage from P-deprived pastures were markedly lower than those in healthy ranges $(P<0.01)$ and the ratio of calcium $(\mathrm{Ca})$ to $\mathrm{P}$ in the $\mathrm{P}$-deprived forages was 11.49:1. $\mathrm{P}$ contents in blood, wool, rib, hip, and teeth from P-deprived Wumeng sheep were also markedly lower than those in healthy sheep $(P<0.01)$. Compared with healthy sheep, the levels of hemoglobin and packed cell volume from $\mathrm{P}$-deficient sheep were significantly lower than those in healthy animals $(P<0.01)$. The levels of creatinine (CRT), lactate dehydrogenase (LDH), and alkaline phosphatase (AKP) in serum were significantly higher and the inorganic phosphorus (IP) value was significantly lower in P-deficient compared with healthy sheep $(P<0.01)$. Contents of $\alpha$-globulin $(\alpha$-GLB) and $\beta$-globulin $(\beta$-GLB) in serum from $\mathrm{P}$-deficient sheep were markedly higher than those in healthy sheep $(P<0.01)$. Serum $\gamma$-globulin $(\gamma$-GLB) was significantly lower than that in healthy sheep $(P<0.01)$. Therefore, $\mathrm{P}$ deprivation in forage not only influenced the mineral content in animal tissue, but also severely disrupted blood parameters (physiology, biochemistry) in Wumeng sheep.
\end{abstract}

Keywords: the Wumeng sheep, response, phosphorus deprivation, southwest China

\section{Introduction}

The Wumeng sheep is an important livestock for stock farming in the Southwest China [1]. During the past 10 years, the Wumeng sheep have been affected by

*e-mail: xyshen@swust.edu.cn phosphorus (P) deprived pastures [2]. Affected Wumeng sheep are characterized as emaciation, lameness, muscular relaxation, enlargement of the costochondral junctions, stiffness of extremities, and abnormal curvature in long bones [3]. Severe affected Wumeng sheep included permanent recumbency and eventual death. Many scholars have studied animal mineral deficiencies in the whole world $[4,5]$. Huang (2002) reported sulfur (S) deficiency in Tibet sheep and goats 
causing by low $\mathrm{S}$ content in soil and forage in pasture in Gansu Province in the Northwest China [6]. Bano (2019) and Çelebi (2019) reported selenium (Se) deficiency in some patients caused by low Se content in feed [7, 8]. Shen et al (2019) and Chi (2019) reported Se deficiency in the wildlife causing by Se deprived natural habitat in Qinghai-Tibet Plateau in the Northwest China [9, 10]. Huo et al (2019) reported the Se-deficient Wumeng semi-fine wool sheep, and mainly caused by the low Se content in soil and feed [11]. Song et al (2019) studied the zinc $(\mathrm{Zn})$ deficiency in Wumeng semi-fine wool sheep, mainly caused by the low Zn content in soil and forage [12]. The P deprived wild yaks were found in the east part of Qinghai-Tibet plateau, mainly caused by low P contents of soil and forage [13]. The P-deprived Tibet sheep were found in Weining County in Wumeng Mountains of China, mainly caused by fenced pastures [14]. Other scholars have found similar phenomena in other animals [15], such as pigs [16], dogs [17], cows [18] and camels [19]. However, the P-deprived Wumeng sheep have not been report yet.

The objective of this study is to determine effects of P-deprived pastures on the grazing Wumeng sheep, and to provide reference for solving the problem of $\mathrm{P}$ deficiency in the Wumeng sheep.

\section{Materials and Methods}

\section{Site History and Description}

The P-deprived pasture is $28.6-29.7^{\circ} \mathrm{N}$ latitude, and $104.2-105.2^{\circ} \mathrm{E}$ longitude, at an average elevation of $2500 \mathrm{~m}$ above sea level. It had been a fine range, belonging to the whole County until 2010 when the local government allocated both the ranges and sheep to individual family, to improve the local herdsman's productivity and nomadic life [20]. All sheep have to graze on P-deficient range throughout the year. As a result, the Wumeng sheep have been severe affected by P-deficient forage. The detailed investigation in the Wumeng sheep was carried out in the studied area. Collected data included the ecological condition, the character, history, incidence, and regularity of affected animals. Clinical sign was recorded by directly observing activity of the Wumeng sheep on the pasture. In recent years, our studies have indicated incidences of $29.44 \%$ in Wumeng sheep in severe P-deficient pastures, and mainly occurred in mature females and lambs.

\section{Experimental Design}

20 Wumeng sheep were selected as an experimental group in Salaxi Experimental Station of Guizhou Normal University in Bijie City, China. All affected animals showed emaciation, lameness, muscular relaxation, stiffness of extremities, and abnormal curvature in long bones. 20 Wumeng sheep were selected as the control group in Liangshuigou Farm in Weining County in Guizhou Province of China. All the animals were in good health on clinical examination.

\section{Sample Collections}

20 samples of soil were collected from each pasture, and $1 \times 1 \mathrm{~m}$ quadrats were randomly selected at $200 \mathrm{~m}$ intervals. In each sample area, surface soil samples $(200 \mathrm{~g})$ were collected at a depth of 0 to $30 \mathrm{~cm}$. 20 mixed forage were collected from each pasture. To reduce soil pollution, the forage was collected $0.1 \mathrm{~cm}$ above the ground level [21-23].

The Wumeng sheep in these studies were cared as per outlined in the Guide for the Care and Use of sheep in Research and Teaching Consortium [24]. Collected samples in sheep were approved by the Southwest University of Science and Technology, Animal Care and Use Committee (Project A0077). Wool samples were taken from the neck of the Wumeng sheep, degreased and washed, and kept on silica gel in a desiccator [25]. Blood samples were also obtained from the jugular vein of sheep, and using 1\% sodium heparin as anticoagulant for content of mineral analysis. Serum samples were separated by centrifugation (G: 15000-20000 (ten min), and stored at $-4^{\circ} \mathrm{C}$ in vials [26]. After Wumeng sheep were slaughtered in the study, routinely post-mortem examination was conducted by visually observing the tissue of affected sheep. Samples of hips, ribs and teeth were collected from affected animals to determine mineral elements.

\section{Blood Parameters Examination}

Hemoglobin $(\mathrm{Hb})$, packed cell volume (PCV), white blood cell (WBC), red blood cell (RBC), neutrophils (NE), lymphocytes (LY), eosinophils (EOS), basophils (B), monocytes (M) values were determined by an automated hematology analyzer (SF-3000, SysmexToa Medical Electronic, Kobe, Japan). Electrophoretic examinations of total protein (TP), albumin (ALB), and globulin (GLB) in serum were done on cellulose acetate. Inorganic phosphorus (IP), Lactate dehydrogenase (LDH), $\gamma$-glutamyl transferase $(\gamma$-GT), creatinine (CRT), alkaline phosphatase (AKP), calcium (Ca) were determined using automatic biochemical analyzer (OLYMPUS AU 640, Olympus Optical Co., Japan) [27]. Quality control serum was used to validate serum biochemistry data (Shanghai Biochemical Co).

\section{Examination of Mineral Element Contents}

Contents of iron $(\mathrm{Fe})$, copper $(\mathrm{Cu})$, manganese $(\mathrm{Mn})$, $\mathrm{Ca}, \mathrm{Zn}$, and $\mathrm{P}$ were analyzed by a atomic absorption spectrophotometer (Perkin-Elmer AAS5000, Norwalk, Connecticut, USA) [28, 29]. Content of molybdenum (Mo) was analyzed by a flameless atomic absorption spectrophotometry (Perkin-Elmer 3030 graphite furnace with a Zeeman background correctiont, USA). 
Table 1. Mineral contents in soil and forage in P-deficient and healthy pasture.

\begin{tabular}{|c|c|c|c|c|}
\hline \multirow{2}{*}{ Elements } & \multicolumn{2}{|c|}{ Soil } & \multicolumn{2}{c|}{ Forage } \\
\cline { 2 - 5 } & Deficient pasture & Healthy pasture & P-deficient pasture & Healthy pasture \\
\hline $\mathrm{Cu}(\mathrm{mg} / \mathrm{kg})$ & $18.62 \pm 2.54$ & $18.88 \pm 2.61$ & $6.64 \pm 2.81$ & $6.71 \pm 2.82$ \\
\hline $\mathrm{Mo}(\mathrm{mg} / \mathrm{kg})$ & $1.21 \pm 0.31$ & $1.21 \pm 0.32$ & $1.24 \pm 0.22$ & $1.81 \pm 0.22$ \\
\hline $\mathrm{Fe}(\mathrm{mg} / \mathrm{kg})$ & $4156.77 \pm 332.56$ & $4408.89 \pm 321.36$ & $363.56 \pm 40.97$ & $373.47 \pm 41.44$ \\
\hline $\mathrm{Zn}(\mathrm{mg} / \mathrm{kg})$ & $23.82 \pm 5.41$ & $24.34 \pm 5.11$ & $5.51 \pm 1.19$ & $5.34 \pm 1.86$ \\
\hline $\mathrm{Mn}(\mathrm{mg} / \mathrm{kg})$ & $54.68 \pm 12.64$ & $54.74 \pm 12.31$ & $12.19 \pm 2.83$ & $12.41 \pm 3.65$ \\
\hline $\mathrm{Ca}(\mathrm{mg} / \mathrm{kg})$ & $8268.67 \pm 236.33$ & $5779.67 \pm 223.46$ & $2569.77 \pm 125.56$ & $2689.87 \pm 123.66$ \\
\hline $\mathrm{P}(\mathrm{mg} / \mathrm{kg})$ & $34.63 \pm 3.51^{\mathrm{a}}$ & $87.67 \pm 6.71$ & $223.66 \pm 12.78^{\mathrm{a}}$ & $1231.98 \pm 33.67$ \\
\hline $\mathrm{Ca}: \mathrm{P}$ & $238.77: 1$ & $66.92: 1$ & $11.49: 1$ & $2.18: 1$ \\
\hline
\end{tabular}

${ }^{a}$ Results between $\mathrm{P}$-deficient and healthy pastures were greatly different $(P<0.01)$.

$\mathrm{Fe}=$ iron; $\mathrm{Cu}=$ copper; $\mathrm{Mo}=$ molybdenum; $\mathrm{Mn}=$ manganese $\mathrm{Zn}=$ zinc; $\mathrm{P}=$ phosphorus; $\mathrm{Ca}=$ calcium .

The accuracy of the analytical contents was checked by reference to certified values of mineral elements in the National Bureau of Standards (NBS) (bovine liver NBS 1577c) $[30,31]$.

\section{Statistical Examinations}

Experimental data were analyzed by using the statistical package (SPSS, version 23.0, Inc., Chicago, Illinois, USA). Data are presented as means \pm S.D., and values were considered to be statistically significant at $P<0.01$.

\section{Results}

Detailed Investigations of Animal and Environment

$\mathrm{P}$ contents in herbage and soil from P-deficient range were markedly lower than those in healthy pasture $(P<0.01)$ (Table 1). $\mathrm{P}$ contents in the herbage from healthy pasture were 5.51 times higher than those in P-deficient area. The Ca:P ratio of herbage in the P-deficient range was about 11.49:1. Other mineral contents were within the healthy ranges.

In previous clinical investigations, the $\mathrm{P}$ deficiency in Wumeng sheep mainly occurred in lambs and mature females throughout the year, with a peak incidence between July and October. Post-partum and pregnant females were most commonly affected by P deficiency. The signs were less obvious in mature males. In severe P-deficient pastures, $29.44 \%$ of the Wumeng sheep were affected by P-deficient forage and the mortality reached $44.83 \%$. Besides the symptoms described above, long bones were broken frequently without apparent stress. However, as shown in Table 2, respiratory rate, body temperature, and heart rate from affected sheep were healthy.

\section{Mineral Contents in Sheep Tissues}

$\mathrm{P}$ contents in wool and blood from affected Wumeng sheep were markedly lower than those in healthy sheep $(P<0.01)$ (Table 3$)$. $\mathrm{P}$ concentrations in hips, ribs, and teeth from affected sheep were also greatly lower than those in healthy sheep $(P<0.01)$ (Table 4). There were no marked differences in other mineral contents between healthy sheep and affected sheep.

\section{Effect of P-deficient Sheep on Hematological Parameters}

Hematological parameters are given in Table 5 . Compared with healthy sheep, the levels of $\mathrm{Hb}$ and

Table 2. Effect of pasture P deficiency on clinical measurements in sheep.

\begin{tabular}{|c|c|c|c|c|c|c|}
\hline Characteristic & $\begin{array}{c}\text { Male } \\
(20)^{\mathrm{a}}\end{array}$ & $\begin{array}{c}\text { Non-pregnant } \\
(20)^{\mathrm{a}}\end{array}$ & $\begin{array}{c}\text { Pregnant } \\
(20)^{\mathrm{a}}\end{array}$ & $\begin{array}{c}\text { Ante-partum } \\
(20)^{\mathrm{a}}\end{array}$ & $\begin{array}{c}\text { Post-partum } \\
(20)^{\mathrm{a}}\end{array}$ & $\begin{array}{c}\text { Lamb } \\
(20)^{\mathrm{a}}\end{array}$ \\
\hline Temperature $\left({ }^{\circ} \mathrm{C}\right)$ & $37.42 \pm 0.37$ & $37.32 \pm 0.31$ & $37.27 \pm 0.29$ & $38.17 \pm 0.15$ & $37.56 \pm 0.19$ & $37.76 \pm 0.17$ \\
\hline Heart rate (beats/min) & $57.71 \pm 2.96$ & $58.83 \pm 2.67$ & $59.97 \pm 2.75$ & $59.74 \pm 2.26$ & $59.65 \pm 2.93$ & $59.78 \pm 2.93$ \\
\hline $\begin{array}{c}\text { Respiratory rate (breaths/ } \\
\text { min) }\end{array}$ & $18.39 \pm 2.73$ & $18.32 \pm 2.52$ & $18.59 \pm 2.39$ & $19.27 \pm 2.74$ & $19.35 \pm 2.37$ & $21.37 \pm 2.37$ \\
\hline
\end{tabular}

${ }^{a}$ Number of all samples 
Table 3. Effect of pasture P deficiency on selected elemental composition of blood and wool samples.

\begin{tabular}{|c|c|c|c|c|}
\hline \multirow{2}{*}{ Elements } & \multicolumn{2}{|c|}{ Blood } & \multicolumn{2}{c|}{ Wool } \\
\cline { 2 - 5 } & P-deficient sheep & Healthy sheep & P-deficient sheep & Healthy sheep \\
\hline $\mathrm{Cu}(\mathrm{mg} / \mathrm{kg})$ & $0.81 \pm 0.19$ & $0.83 \pm 0.21$ & $5.26 \pm 1.34$ & $5.24 \pm 1.23$ \\
\hline $\mathrm{Mo}(\mathrm{mg} / \mathrm{kg})$ & $0.41 \pm 0.07$ & $0.43 \pm 0.01$ & $0.42 \pm 0.13$ & $0.41 \pm 0.05$ \\
\hline $\mathrm{Fe}(\mathrm{mg} / \mathrm{kg})$ & $541.76 \pm 24.43$ & $542.57 \pm 25.65$ & $361.65 \pm 27.76$ & $341.88 \pm 17.78$ \\
\hline $\mathrm{Zn}(\mathrm{mg} / \mathrm{kg})$ & $15.68 \pm 2.91$ & $15.24 \pm 2.69$ & $86.64 \pm 4.95$ & $88.41 \pm 3.81$ \\
\hline $\mathrm{Mn}(\mathrm{mg} / \mathrm{kg})$ & $0.62 \pm 0.23$ & $0.63 \pm 0.21$ & $5.84 \pm 1.34$ & $5.41 \pm 1.34$ \\
\hline $\mathrm{Ca}(\mathrm{mg} / \mathrm{kg})$ & $132.56 \pm 14.47$ & $132.44 \pm 14.37$ & $1214.12 \pm 35.56$ & $1209.45 \pm 63.76$ \\
\hline $\mathrm{P}(\mathrm{mg} / \mathrm{kg})$ & $254.67 \pm 26.56^{\mathrm{a}}$ & $392.77 \pm 33.65$ & $63.57 \pm 12.84^{\mathrm{a}}$ & $98.64 \pm 14.54$ \\
\hline
\end{tabular}

${ }^{a}$ Results between P-deficient and healthy sheep were greatly different $(P<0.01)$.

$\mathrm{Fe}=$ iron; $\mathrm{Cu}=$ copper; $\mathrm{Mo}=$ molybdenum; $\mathrm{Mn}=$ manganese; $\mathrm{Zn}=$ zinc; $\mathrm{P}=$ phosphorus; $\mathrm{Ca}=$ calcium.

Table 4. Effect of pasture P deficiency on selected elemental composition of rib, hip, and teeth samples in sheep.

\begin{tabular}{|c|c|c|c|c|c|c|}
\hline \multirow{2}{*}{ Elements } & \multicolumn{2}{|c|}{ Rib } & \multicolumn{2}{c|}{ Hip } & \multicolumn{2}{c|}{ Teeth } \\
\cline { 2 - 7 } & P-deficient sheep & Healthy sheep & P-deficient sheep & Healthy sheep & P-deficient sheep & Healthy sheep \\
\hline $\mathrm{Cu}(\mathrm{mg} / \mathrm{kg})$ & $6.33 \pm 0.59$ & $6.48 \pm 0.51$ & $5.79 \pm 0.56$ & $5.91 \pm 0.38$ & $4.63 \pm 0.53$ & $4.65 \pm 0.72$ \\
\hline $\mathrm{Mo}(\mathrm{mg} / \mathrm{kg})$ & $1.17 \pm 0.21$ & $1.15 \pm 0.23$ & $2.53 \pm 0.26$ & $2.57 \pm 0.33$ & $2.45 \pm 0.36$ & $2.36 \pm 0.26$ \\
\hline $\mathrm{Fe}(\mathrm{mg} / \mathrm{kg})$ & $165.77 \pm 7.62$ & $166.57 \pm 9.13$ & $163.51 \pm 9.73$ & $167.25 \pm 8.84$ & $156.76 \pm 9.45$ & $154.83 \pm 10.25$ \\
\hline $\mathrm{Zn}(\mathrm{mg} / \mathrm{kg})$ & $119.67 \pm 8.56$ & $119 \pm 7.98$ & $83.31 \pm 5.83$ & $87.57 \pm 5.26$ & $86.23 \pm 4.58$ & $85.45 \pm 5.14$ \\
\hline $\mathrm{Mn}(\mathrm{mg} / \mathrm{kg})$ & $7.53 \pm 1.35$ & $7.65 \pm 1.21$ & $5.57 \pm 0.57$ & $5.47 \pm 0.45$ & $6.24 \pm 0.47$ & $6.21 \pm 0.54$ \\
\hline $\mathrm{Ca}(\mathrm{mg} / \mathrm{kg})$ & $139.77 \pm 7.65$ & $137.96 \pm 8.12$ & $121.57 \pm 9.73$ & $119.97 \pm 7.65$ & $164.67 \pm 9.84$ & $173.65 \pm 10.25$ \\
\hline $\mathrm{P}(\mathrm{mg} / \mathrm{kg})$ & $37.33 \pm 2.37^{\mathrm{a}}$ & $75.72 \pm 8.67$ & $35.71 \pm 3.29^{\mathrm{a}}$ & $76.37 \pm 8.17$ & $34.46 \pm 4.16^{\mathrm{a}}$ & $75.28 \pm 7.29$ \\
\hline
\end{tabular}

${ }^{a}$ Results between P-deficient and healthy sheep were greatly different $(P<0.01)$.

$\mathrm{Fe}=$ iron; $\mathrm{Cu}=$ copper; $\mathrm{Mo}=$ molybdenum; $\mathrm{Mn}=$ manganese; $\mathrm{Zn}=$ zinc $; \mathrm{P}=$ phosphorus; $\mathrm{Ca}=$ calcium.

PCV from P-deficient sheep were significantly lower than those in healthy animals $(P<0.01)$.

\section{Effect of P-deficient Sheep on Bones}

Visual autopsy examinations showed that gross bone lesions of affected mature ewes and lambs from P-deficient pasture were similar. Almost all bones, particularly the scapula, ilium, ribs, mandible, and hip bone were seriously affected by $\mathrm{P}$ deficiency. The bones of affected sheep were brittle, porous, light, susceptible to fracturing, and easier to be cut and sewn. The marrow cavities of affected sheep were enlarged and extended to the epiphysis, and the cortex was spongy, thin, and soft.

Proximal humerus of affected sheep has showed flattening of the humeral head and separation of articular cartilage from collapsed subchondral bone. The segmental thickening of the physis, thickened metaphyseal trabeculae, and thickened cortices in proximal humerus in P-lacking sheep. Distal femur from affected sheep shows segmental physeal
Table 5. Effect of pasture $\mathrm{P}$ deficiency on hematological measurements in sheep.

\begin{tabular}{|c|c|c|}
\hline Parameters & P-deficient sheep & Healthy sheep \\
\hline $\mathrm{Hb}(\mathrm{g} / \mathrm{L})$ & $117.83 \pm 5.53^{\mathrm{a}}$ & $123.57 \pm 7.67$ \\
\hline $\mathrm{RBC}\left(10^{12} / \mathrm{L}\right)$ & $12.57 \pm 1.52$ & $12.65 \pm 1.27$ \\
\hline $\mathrm{PCV}(\%)$ & $31.77 \pm 3.56^{\mathrm{a}}$ & $39.69 \pm 3.77$ \\
\hline $\mathrm{WBC}\left(10^{9} / \mathrm{L}\right)$ & $7.11 \pm 0.78$ & $7.12 \pm 0.83$ \\
\hline $\mathrm{NE}(\%)$ & $59.78 \pm 3.65$ & $58.99 \pm 3.56$ \\
\hline $\mathrm{LY}(\%)$ & $31.72 \pm 2.79$ & $32.66 \pm 2.39$ \\
\hline $\mathrm{EOS}(\%)$ & $6.77 \pm 0.63$ & $6.69 \pm 0.59$ \\
\hline $\mathrm{B}(\%)$ & $0.55 \pm 0.01$ & $0.57 \pm 0.02$ \\
\hline $\mathrm{M}(\%)$ & $7.25 \pm 0.56$ & $7.37 \pm 0.55$ \\
\hline
\end{tabular}

${ }^{a}$ Results between P-deficient and healthy sheep were greatly different $(P<0.01)$.

$\mathrm{Hb}=$ hemoglobin; $\mathrm{PCV}=$ packed cell volume; $\mathrm{RBC}=$ red blood cells; $\mathrm{WBC}=$ white blood cells; $\mathrm{NE}=$ neutrophils; $\mathrm{LY}=$ lymphocytes; $\mathrm{EOS}=$ eosinophils; $\mathrm{B}=$ basophils; $\mathrm{M}=$ monocytes. 
thickening. Impaired provisional calcification of cartilage at sites of endochondral ossification leads to the accumulation of hypertrophic chondrocytes, resulting in thickened and irregular growth plates with islands and tongues of chondrocytes extending into the metaphyses. Enlargement of joints with apparent bowing of long bone and broadening of the epiphyses were typical of P-lacking sheep. Irregular ulcer was sometimes seen on the surface of joint in P-lacking sheep. Lesions are typically most severe in the fastestgrowing bones, including the radius, the tibia, and the metacarpals and metatarsals. Similar changes in affected sheep occur beneath articular epiphyseal cartilage complexes in the expanding epiphyses. Other microscopic changes include thick osteoid seams lining trabeculae and disorganization in affected sheep. Hemorrhage and signs of trauma in affected sheep were seen in the metaphysis and primary spongiosa because of damage to weakened trabeculae of poorly mineralized bone. There were no marked differences in other elements between healthy Wumeng sheep and P-deprived ones.

\section{Effect of P-deficient Sheep on Biochemical Parameters}

The levels of CRT, LDH, and AKP in serum were significantly higher and the IP value was significantly lower in P-deficient compared with healthy sheep $(P<0.01)$ (Table 6).

\section{Effect of P-deficient Sheep on Serum Protein Contents}

As shown in Table 7, contents of $\alpha$-GLB and $\beta$-GLB in serum from P-deficient sheep were markedly higher than those in healthy sheep $(P<0.01)$. Serum $\gamma$-GLB was significantly lower than that in healthy Wumeng sheep $(P<0.01)$.

Table 6. Effect of pasture P deficiency on selected biochemical measurements in sheep.

\begin{tabular}{|c|c|c|}
\hline Blood parameters & P-deficient sheep & Healthy sheep \\
\hline $\mathrm{LDH}(\mu \mathrm{moL} / \mathrm{L})$ & $6.73 \pm 1.21^{\mathrm{a}}$ & $4.15 \pm 0.37$ \\
\hline$\gamma$-GT $(\mathrm{IU} / \mathrm{L})$ & $26.67 \pm 2.63$ & $26.35 \pm 2.57$ \\
\hline $\mathrm{AKP}(\mathrm{IU} / \mathrm{L})$ & $137.26 \pm 8.77^{\mathrm{a}}$ & $67.56 \pm 3.53$ \\
\hline $\mathrm{CRT}(\mu \mathrm{moL} / \mathrm{L})$ & $157.89 \pm 12.33^{\mathrm{a}}$ & $113.45 \pm 11.31$ \\
\hline $\mathrm{Ca}(\mathrm{mmoL} / \mathrm{L})$ & $2.77 \pm 0.23$ & $2.73 \pm 0.21$ \\
\hline $\mathrm{IP}(\mathrm{mmoL} / \mathrm{L})$ & $1.23 \pm 0.17^{\mathrm{a}}$ & $2.77 \pm 0.29$ \\
\hline
\end{tabular}

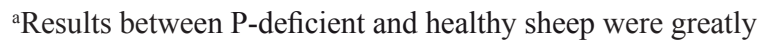
different $(P<0.01)$.

$\mathrm{LDH}=$ Lactate dehydrogenase; $\mathrm{AKP}=$ alkaline phosphatase; $\gamma$-GT $=\gamma$-glutamyl transferase; $\mathrm{CRT}=$ creatinine; $\mathrm{Ca}=$ calcium;

$\mathrm{IP}=$ inorganic phosphorus.
Table 7. Effect of pasture $\mathrm{P}$ deficiency on serum protein measurements in sheep.

\begin{tabular}{|c|c|c|}
\hline Protein parameters & P-deficient sheep & Healthy sheep \\
\hline TP $(g / L)$ & $62.53 \pm 3.27$ & $66.89 \pm 3.56$ \\
\hline ALB $(g / L)$ & $44.17 \pm 3.65$ & $45.91 \pm 3.69$ \\
\hline$\alpha-G L B(g / L)$ & $3.89 \pm 0.33^{\mathrm{a}}$ & $2.99 \pm 0.25$ \\
\hline$\beta-G L B(g / L)$ & $4.72 \pm 0.42^{\mathrm{a}}$ & $3.26 \pm 0.35$ \\
\hline$\gamma-G L B(g / L)$ & $9.75 \pm 0.34^{\mathrm{a}}$ & $14.73 \pm 1.17$ \\
\hline A/G & $2.41 \pm 0.25$ & $2.19 \pm 0.27$ \\
\hline
\end{tabular}

${ }^{a}$ Results between $\mathrm{P}$-deficient and healthy sheep were greatly different $(P<0.01)$.

$\mathrm{TP}=$ total protein; $\mathrm{ALB}=$ albumin; $\alpha-\mathrm{GLB}=\alpha$-globulin; $\beta$-GLB $=\beta$-globulin; $\gamma$-GLB $=\gamma$-globulin; $\mathrm{A} / \mathrm{G}=$ albumin $/$ globulin.

\section{Discussion}

The main signs of affected animals included losing appetite, emaciation, pica, anemia, necrosis of skeletal muscle and weight loss. This result showed that the $\mathrm{P}$ contents in the soil and forage from P-deficient ranges were markedly lower than healthy areas $(P<0.01)$. In addition, $\mathrm{P}$ values in blood, wool, bones, and teeth from P-deficient Wumeng sheep were greatly lower, and serum AKP value was markedly higher than those in healthy Wumeng sheep. The results were consistent with the response criteria in P deficiency of camels, cattle and yaks. The results demonstrated that the mineral deficiency in the Wumeng sheep was related to P-deficient ranges.

The local herd practices have a great impact on mineral element imbalance of grazing livestock and wildlife in China [32]. In 2000s, the pasture and livestock were allocated to individual family. As a result, the fenced pasture might create mineral element imbalance question for grazing animals. Mineral contents in the soil and herbage are spatially distributed $[33,34,35]$. If sheep graze in an extensive area, they have chances to foraging herbage of including rich mineral. As a result, there are few mineral deficiencies in grazing sheep $[36,37]$. In this study, $\mathrm{P}$ contents in soil and herbage from P-deficient ranges were markedly lower than that in the healthy pasture $(P<0.01)$. The Wumeng sheep were grazed in P-deficient ranges during the year. As a result, the Wumeng sheep suffered the $\mathrm{P}$ deficiency.

For many forage species, the period with relatively high $\mathrm{P}$ content available to grazing livestock are very short [38]. In most years, mature herbage contains $P<0.15 \%[39,40]$. Adequate $\mathrm{P}$ contents in sheep are $>0.00500 \%$ in soil and $>0.30000 \%$ in herbage [41, 42]. In this study, $P$ contents in soil and herbage from P-deficient ranges were $0.00346 \%$ and $0.02230 \%$, respectively, which were greatly lower than the sufficient contents for sheep. 
Among the factors influencing $\mathrm{P}$ and $\mathrm{Ca}$ utilization metabolism, a mean $\mathrm{Ca}: \mathrm{P}$ ratio of $1: 1$ to $2: 1$ is recommended for proper utilization of the mineral elements by livestock [43, 44]. Dietary Ca:P ratios $<1: 1$ or $>7: 1$ should adversely affect the growth and feed efficiency of livestock [45, 46]. In our study, the $\mathrm{Ca}: \mathrm{P}$ ratio in forage from the healthy area was 2.18:1. However, the Ca:P ratio in herbage from the P-deficient ranges was about 11.49:1, which should have a negative impact on the $\mathrm{Ca}$ and $\mathrm{P}$ metabolism in the Wumeng sheep.

Some response criteria have been used to assess the $\mathrm{P}$ status of livestock, including serum values of $\mathrm{P}, \mathrm{Ca}$, and AKP [47]. Previous study showed that bone criteria are more sensitive to $\mathrm{P}$ than to other mineral elements $[48,49]$. A marked hypophosphataemia is also a fine indicator in a severe P-deficient animal, even if serum contents of $\mathrm{Ca}$ are healthy. The $\mathrm{P}$ contents in blood are not a fine indicator of the $\mathrm{P}$ status, because the $\mathrm{P}$ contents can be normal for a long period after livestock are exposed to severe P-deficient environment [50].

\section{Conclusion}

According to the studied results, $\mathrm{P}$ deficiency in Wumeng sheep is mainly caused by low P contents in the soil and forage. $\mathrm{P}$ deprivation in forage not only influenced the mineral content of the blood, wool, rib, hip, and teeth, but also severely disrupted the blood parameters in Wumeng sheep. Depending on the causes of low $\mathrm{P}$, oral administration of disodium hydrogen phosphate $\left(\mathrm{Na}_{2} \mathrm{HPO}_{4}\right)$ can prevent and cure the disease, and provide reference for solving the problem of $\mathrm{P}$ deficiency in the Wumeng sheep.

\section{Acknowledgements}

This study was supported by the Project of National Key Research and Development Program of China in $13^{\text {th }}$ five-year plan (2016YFC0502601) and National Natural Science Foundation of China (41671041).

\section{Conflict of Interest}

The authors declare that they have no conflict of interest.

\section{Ethics Statement}

The Wumeng sheep in these studies were cared as per outlined in the Guide for the Care and Use of sheep in Research and Teaching Consortium. Collected samples in sheep were approved by the Southwest University of Science and Technology, Animal Care and Use Committee (Project A0077).

\section{References}

1. WU T., SONG M.L., SHEN X.Y. Seasonal dynamics of copper deficiency in Wumeng semi-fine wool sheep. Biological Trace Element Research, 197, 487, 2020. https:// doi.org/10.1007/s12011-019-02018-5

2. CHI Y.K., ZHANG Z.Z., SONG C.J., XIONG K.N., SHEN X.Y. Effects of fertilization on physiological and biochemical parameters of Wumeng sheep in China's Wumeng Prairie. Polish Journal of Environmental Studi es, 29 (1), 79-85, 2019.

3. YAN Q.X., TANG S.X., BAMIKOLE M.A.B., HAN X.F., ZHOU C.S., WANG M., SUN Z.H., TAN Z.L. Influences of dietary phosphorus variation on nutrient digestion, fecal endogenous phosphorus output and plasma parameters of goats. Livestock Science, 142 (1-3), 63, 2011.

4. HUO B., WU T., SONG C.J., SHEN X.Y. Effects of selenium deficiency in the environment on antioxidant systems of Wumeng semi-fine wool sheep. Polish Journal of Environmental Studies, 29 (2), 1, 2020. https://doi. org/10.15244/pjoes/109492

5. LAGOCKA R., SIKORSKA-BOCHINSKA J., NOCEN I., JAKUBOWSKA K., GORA M., BUCZKOWSKARADLINSKA J. Influence of the mineral composition of drinking water taken from the surface water intake in enhancing regeneration processes in mineralized human teeth tissue. Polish Journal of Environmental Studies, 20 (2), 411, 2011

6. CHI Y.K., HUO B., SHEN X.Y. Study on the distribution characteristics of selenium nutrition on the natural habitat of Przewalski's gazelle. Polish Journal of Environmental Studies, 29 (1), 67, 2020.

7. BANO I., MALHI M., KHATRI P., SOOMRO S.A., SAJJAD H., LEGHARI A., AWAIS M., KANDHRO S., LAKHO S.A., SOOMRO M. Effect of dietary selenium yeast supplementation on morphology and antioxidant status in testes of young goat. Pakistan Journal of Zoology, 51 (3), 979, 2019.

8. ÇELEBI Ş. Effect of dietary vitamin E, selenium and their combination on concentration of selenium, MDA, and antioxidant enzyme activities in some tissues of laying hens. Pakistan Journal of Zoology, 51 (3), 1155, 2019.

9. SHEN X.Y., HUO B., WU T., SONG C.J., CHI Y.K. iTRAQ-based proteomic analysis to identify molecular mechanisms of the selenium deficiency response in the Przewalski's gazelle. Journal of Proteomics, 203,103389, 2019. https://doi.org/10.1016/j.jprot.2019.103389

10. WU T., SHEN X.Y. Response of Wumeng semi-fine wool sheep to copper contaminated environment. Polish Journal of Environmental Studies, 29 (4), 2917-2924, 2020. https:// doi.org/10.15244/pjoes/111881

11. HUO B., WU T., SONG C.J., SHEN X.Y. Studies of selenium deficiency in the Wumeng semi-fine wool sheep. Biological Trace Element Research, 194 (1), 152-158, 2019.

12. SONG C.J., SHEN X.Y. Effects of Environmental zinc deficiency on antioxidant system function in Wumeng semi-fine wool sheep. Biological Trace Element Research, 195, 110-116, 2019.

13. SHEN X.Y., ZHANG R.D. Studies on "stiffness of extremities disease" in the yak (bos mutus). Journal of Wildlife Diseases, 48 (3), 542-547, 2012.

14. SHEN X.Y., CHI Y.K., HUO B., WU T., XIONG K.N. Effect of fertilization on ryegrass quality and mineral metabolism in grazing the Wumeng semi-fine wool sheep. Fresenius Environmental Bulletin, 26 (10), 6824, 2018. 
15. PRASAD R. Micro mineral nutrient deficiencies in humans, animals and plants and their amelioration. Proceedings of the National Academy of Sciences, India Section B: Biological Sciences, 82 (2), 2253, 2012.

16. O'FLYNN C.J., FENTON O., WALL D.P., BRENNAN R., MCLAUGHLIN M.J., HEALY M.G. Influence of soil phosphorus status, texture, $\mathrm{pH}$ and metal content on the efficacy of amendments to pig slurry in reducing phosphorus losses. Soil Use and Management, 34 (1), 1, 2018.

17. LINEVA A., KIENZLE E., DOBENECKER B. Investigations on dietary phosphorus solubility in water and acid medium from foods and mineral sources used for dog and cat nutrition, ESVCN Congress: Cirencester, Great Britain, 2017.

18. LOPES S.P., GARCIA F.Z., SOUZA V.C., COSTA D.F.A., MALAFAIA P. Bio-economic evaluation of a reduced phosphorus supplementation strategy for a cow-calf system in Brazil: a case study. Tropical Animal Health and Production, 50 (1), 205, 2018.

19. LIU Z.P. Studies on rickets and osteomalacia in Bactrian camels (Camelus bactrianus). The Veterinary Journal, 169 (3), 444, 2005.

20. CHI Y.K., XIONG K.N., CHEN H., MIN X.Y., XIAO H., LIAO J.J., SHEN X.Y. Effect of grazing to copper pollution meadow on copper metabolism in Wumeng semi-fine wool sheep. Polish Journal of Environmental Studies, 28 (3), 1083, 2019.

21. SONGC.J., JIANG Q., SHEN X.Y. Responses of Przewalski's Gazelle (Procapra przewalskii) to zinc nutrition in physical habitat. Biological Trace Element Research, 2020. https://doi.org/10.1007/s12011-02002137-4

22. SHEHZAD M.T., MURTAZA G., SHAFEEQUE M., SABIR M., NAWAZ H., KHAN M.J. Assessment of trace elements in urban topsoils of Rawalpindi-Pakistan: a principal component analysis approach. Environmental Monitoring and Assessment, 191 (2), 65, 2019.

23. ZHAO K., CHI Y.K., SHEN X.Y. Studies on edema pathema in Hequ horse in the Qinghai-Tibet Plateau. Biological Trace Element Research, 2020. https://doi. org/10.1007/s12011-020-02043-9

24. VAUGHN S.E. FASS Guide for the Care and Use of Agricultural Animals in Research and Teaching, $3^{\text {rd }}$ ed.; Federation of Animal Science Societies: Champaign, IL, US, 2010.

25. SALMELA S., VUORI E., KILPIÖ J.O. The effect of washing procedures on trace element content of human hair. Analytica Chimica Acta, 125, 131, 1981.

26. CHI Y.K., CHEN Y.B., SONG S.Z., SHEN X.Y. Effect of zinc nutrition on blood parameters of Wumeng semi-fine sheep in nature habitat. Fresenius Environmental Bulletin, 28 (5), 3886, 2019.

27. SOBOTA S., BARANOWSKA-BOSIACKA I., GUTOWSKA I., KUPIEC M., DUSZA E., MACHOY Z., CHLUBEK D. Biomonitoring of lead and fluoride contamination in forests using chemical analysis of hard tissues of roe deer (Capreolus capreolus L.). Polish Journal of Environmental Studies, 20 (2), 435, 2011.

28. TAYO G.O., TANG S.X., TAN Z.L., SUN Z.H., WANG M., ZHOU C.S., HAN X.F. Determination of endogenous faecal phosphorus loss in goats. Archives of Animal Nutrition, 63 (2), 104, 2009.

29. HUANG Y.D., CHEN H.T. Studies on the pathogenesis of Shimao Zheng (fleece-eating) in sheep and goats. Veterinary Research Communications, 25 (8), 631, 2001.
30. CHI Y.K., HUANG D.H., SONG S.Z., HUO B., WU T., SONG C.J., SHEN X.Y. Effect of seasonal variation on mineral nutrient of forage in habitat of Przewalski's gazelle (Procapra przewalskii). Fresenius Environmental Bulletin, 28 (2A), 1457, 2019.

31. SHEN X.Y., ZHANG J.H., ZHANG R.D. Phosphorus metabolic disorder of Guizhou semi-fine wool sheep. Plos One, 9 (2), 2014.

32. SUTTLE N.F. Mineral nutrition of livestock, $4^{\text {th }}$ ed.; CABI (CAB International): Wallingford, UK, 2010.

33. SAWICKA B., KROCHMAL-MARCZAK B. Relationship between physical and chemical properties of soil and iron, manganese and zinc content in a grain of winter wheat. Polish Journal of Environmental Studies, 17, 278, 2008.

34. HUO B., HE J., SHEN X.Y. Effects of selenium-deprived habitat on the immune index and antioxidant capacity of Przewalski's gazelle. Biological Trace Element Research, 2020. https://doi.org/10.1007/s12011-020-02070-6

35. SONG C.J., GAN S.Q., SHEN X.Y. Effects of nanocopper poisoning on immune and antioxidant function in the Wumeng semi-fine wool sheep. Biological Trace Element Research, 2020. https://doi.org/10.1007/s12011020-02085-z

36. KARN J.F. Phosphorus nutrition of grazing cattle: a review. Animal Feed Science and Technology, 89 (3-4), 133, 2001.

37. MCDOWELL L.R. Minerals in animal and human nutrition, $2^{\text {nd }}$ ed.; Elsevier Science BV: Amsterdam, The Netherlands, 2003.

38. RODEHUTSCORD M., HEUVERS H., PFEFFER E. Effect of organic matter digestibility on obligatory faecal phosphorus loss in lactating goats, determined from balance data. Animal Science, 70 (3), 561, 2000.

39. SCOTT D., BUCHAN W. The effects of feeding either roughage or concentrate diets on salivary phosphorus secretion, net intestinal phosphorus absorption and urinary phosphorus excretion in the sheep. Quarterly Journal of Experimental Physiology: Translation and Integration, 70 (3), 365, 1985.

40. BRAITHWAITE G.D. Some observations on phosphorus homoeostasis and requirements of sheep. The Journal of Agricultural Science, 102 (2), 295, 1984.

41. FIELD A.C., WOOLLIAMS J.A., DINGWALL R.A. The effect of dietary intake of calcium and dry matter on the absorption and excretion of calcium and phosphorus by growing lambs. The Journal of Agricultural Science, 105 (2), 237, 1985.

42. [CALVO M.S. Dietary phosphorus, calcium metabolism and bone. The Journal of nutrition, 123 (9), 1627-1633, 1993.

43. XIAO D.M., WU Q., FAN W.F., YE X.W., NIU J.Y., GU Y. Effect of serum FGF-23, MGP and fetuin- A on calciumphosphate metabolism in maintenance hemodialysis patients. Hemodialysis International, 17 (4), 483, 2013.

44. MILOVANOVA L.I., DOBROSMYSLOV I.A., MILOVANOV I.S. Experience with active vitamin D metabolites in phosphorus-calcium metabolic disorders in patients with predialysis chronic kidney disease. Therapeutic Archive, 86 (6), 52, 2014.

45. WILKENS M.R., MROCHEN N., BREVES G., SCHRÖDER B. Effects of 1, 25-dihydroxyvitamin D3 on calcium and phosphorus homeostasis in sheep fed diets either adequate or restricted in calcium content. Domestic Animal Endocrinology, 38 (3), 190, 2010.

46. SAKUMA M., SUZUKI A., KIKUCHI M., ARAI H. Soymilk intake has desirable effects on phosphorus and 
calcium metabolism. Journal of clinical biochemistry and nutrition, 62 (3), 259, 2018.

47. ANDERSON J.J.B., DEMPSTER D.W. Dietary Phosphorus and Bone Disease. Clinical Aspects of Natural and Added Phosphorus in Foods. Springer: New York, US, 2017.

48. MAAS C., POHLANDT F., MIHATSCH W.A., FRANZ A.R. Prevention of bone mineral deficiency in premature infants: review of the literature with focus on monitoring of urinary calcium and phosphate. Klinische Padiatrie, 224 (2), 80, 2012 [In German].
49. MAZOURI A., KHOSRAVI N., BORDBAR A., KHALESI N., SABOUTE M., TAHERIFARD P., MIRZABABAEE M., EBRAHIMI M. Does adding intravenous phosphorus to parenteral nutrition has any effects on calcium and phosphorus metabolism and bone mineral content in preterm neonates? Acta Medica Iranica, 55 (6), 395, 2017.

50. GENTRY J., WEBB J., DAVENPORT D., MALLUCHE H.H. Serum phosphorus adds to value of serum parathyroid hormone for assessment of bone turnover in renal osteodystrophy. Clinical Nephrology, 86 (1), 9, 2016. 